Article

\title{
The Implementation of Strategic Management in Greek Hospitality Businesses in Times of Crisis
}

\author{
Sotirios Varelas *(1) and Nikolaos Apostolopoulos \\ Department of Economics and Business, Neapolis University Pafos, 2 Danais Avenue, 8042 Pafos, Cyprus; \\ n.apostolopoulos@nup.ac.cy \\ * Correspondence: s.varelas@nup.ac.cy; Tel.: +357-2684-3436
}

Received: 14 August 2020; Accepted: 31 August 2020; Published: 3 September 2020

\begin{abstract}
The aim of this research was to explore the implementation of strategic management approaches in Greek tourism and hospitality businesses during economic crises, in order to further expand our current knowledge of operating in a turbulent environment and embracing novel aspects by linking economic crises with the current literature on the COVID-19 pandemic. This research emphasizes the connection between the strategic management approaches of 131 tourism organizations and hospitality business performance by analyzing entrepreneurs' opinions and hospitality business markets. The results reveal that a significant percentage of the participants understand and use some strategic management procedures, and some strategy in general, but there is a lack of a concrete strategy for managing the turbulent environment caused by an economic crisis. However, a large percentage of small tourism businesses are completely unaware of strategic management approaches, and their knowledge of implementing a strategy during an economic crisis is limited. The practical implications of this research can act as a navigator of the economic consequences caused by the COVID-19 pandemic.
\end{abstract}

Keywords: strategic management; hospitality business; performance; economic crisis; COVID-19

\section{Introduction}

Tourism is one of the most important pillars of Greek economic growth, accounting for $20.8 \%$ of the gross domestic product (GDP) and $21.7 \%$ of total employment which, before the COVID-19 pandemic, was estimated as totaling 846,200 jobs [1]. However, the recent report from the Bank of Greece [2] revealed a dramatic situation caused by COVID-19, as the tourism revenues for June 2020 were only 64 million euros, in comparison with the 2.56 billion euros of June 2019. The importance of Greek tourism for the economy becomes even greater when considering that the total revenues reached 17.7 billion euros in 2019, according to the official data of the Bank of Greece [2]. Hospitality companies comprise the main sector of Greek tourism development, with a total of 10,121 hotels that offer a capacity of 798,650 beds, according to the latest data of the Hellenic Chamber of Hotels [3]. The importance of Greek tourism is also revealed through academic studies, as in developed countries such as Greece, tourism contributes to economic growth and development [4].

The global financial crisis of 2008 affected the Greek economy and, consequently, the Greek tourism industry after 2010 with the entry of Greece into the International Monetary Fund, mainly due to ever-increasing deficits, the amount of public debt, and the amount of current transactions. One of the main factors that influenced the Greek tourism industry during this time was the prestige and solvency loss of Greece in foreign countries, especially during the loan period, that led to a reduction in disposable income and a reduction in tourism expenditures, especially for Greek families, as their income was reduced by $25 \%$ and they were unable to borrow from the financial system. 
Indeed, the parameters and conditions that influence tourism growth in each country [5] and economic crises together generate a new mosaic of conditions.

Nevertheless, tourism and tourism companies managed to significantly mitigate the effects of the 2008 financial crisis as a result of the continuous rise of inbound tourism, where revenues more than doubled during the crisis period from 9144.5 billion in 2010 to 17.7 billion in 2019. It is worth mentioning that a decisive factor in the rise of revenue and inbound tourism during the decade following the 2008 financial crisis was the Arab Spring and the crisis in North African countries that directed visitors to the rest of the destinations in the Mediterranean Basin. In 2020, Greek tourism entered a new but different crisis due to the COVID-19 pandemic, where the initial forecasts of the Association of Business and Retail Sales of Greece (H.R.B.A.) estimate that revenues will experience a 20-25\% reduction compared to 2019, totaling 4-5 billion euros.

Taking into account the above context of an economic crisis, this paper addresses the recent calls for more extensive research on the strategic management approaches in tourism and hospitality businesses [6-8], along with recent calls linking crises and strategic management in tourism businesses $[9,10]$ and tourist destinations [11]. Furthermore, this paper draws upon the emerged areas of studies exploring strategic decisions and economic crises in Greece [12]. Thus, the aim is to investigate the implementation of strategic management in ages of economic crisis and to expand our existing knowledge in the field. This research can further contribute to understanding the COVID-19 pandemic and the economic impact it will have on the tourism industry. Indeed, the new environment brought about by COVID-19 requires organizations to use a new corporate governance model, new management methods, a new approach to gain customers, and a new way of coping with competition.

In light of this, this paper contributes to the academic debate regarding whether or not hospitality business have embraced strategic management in their operations [8,13]. In addition, it further expands the theoretical discussion on the role of strategic management during periods of crisis [9]. Indeed, despite the many studies that have investigated crises in the tourism sector, the role of strategic management in turbulent times still remains unclear, and this paper contributes to this discussion. In countries that greatly rely on the economic prosperity brought about by tourism, such as Greece, where $20.8 \%$ of the GDP comes from tourism [1], this paper contributes to the practical aspects of designing a supporting policy for hospitality businesses, and evidence of the obstacles and limitations of not implementing a strategic management approach are presented.

Furthermore, this paper contributes to the sustainable development of tourism in the post-COVID-19 period and the economic consequences caused within the tourism industry by the pandemic. Indeed, entrepreneurship can act as a transformational agent with regard to Sustainable Development Goals (SDGs) [14], as in cases of countries with highly developed tourism industries. The economic consequences of COVID-19 will have a negative impact on the eighth SDG of economic prosperity, thus highlighting the need for sustainable development in tourism and hospitality [15]. In the hospitality sector, there is a fear that the economic crisis caused by COVID-19 will reduce commitment to sustainability [16]. However, it is important to maintain sustainable development at the heart of tourism, as sustainability contributes to economic growth [17]. As regards Greece, as stated by the Bank of Greece [2], by June 2020, the revenues from tourism were already $93 \%$ less than those of June 2019. This highlights a severe negative impact on the eighth SDG and, as a consequence, there is an ongoing debate in academic and research circles regarding the opportunity to learn from flaws of the past and to transform the sector toward an economic, social, and environmental path of sustainable development [18-20]. In light of the above, the lessons learned from this paper for dealing with the economic consequences of the 2008 financial crisis can be useful for both academia and policy in the post-COVID-19 hospitality sector, as well as for achieving sustainable economic prosperity.

The remainder of this paper is set out as follows: Section 2 develops the theoretical background of economic crises and strategic management. Section 3 describes the methodological approach 
used in this paper, while Section 4 unfolds the findings and discusses the results of this research. Finally, Section 5 provides concluding remarks, future research avenues, and practical implications.

\section{Theoretical Background}

\subsection{Crises, Tourism, and Hospitality Businesses}

According to the international literature, a significant number of research papers have analyzed the role that crises play in tourism in general, and particularly in the hotel sector, which is also investigated in this research [21]. Global tourism has suffered a series of crises, in terms of both epidemics (e.g., SARS and MERS) and pandemics (most recently COVID-19), as well as financial (e.g., 2008-2009, 2011) and terrorist (e.g., 9/11) crises. Despite such crises, global tourism has shown resilience over time [22]. In particular, financial crises greatly affect tourism revenues by significantly reducing the dynamics of the hotel industry [23], as the disposable income of prospective visitors becomes very limited [24]. Tourism-related employment challenges caused by a crisis are more focused in the Mediterranean region, such as Greece, Cyprus, Croatia, and Turkey, and particularly in Spain [25-28]. Several studies have approached financial crises from a visitor's point of view, focusing on how they are affected in terms of their spending capacity $[29,30]$. Nevertheless, there are few studies that approach such crises from the strategic point of view, specifically in relation to tourism companies. Another strategic approach was developed that studied the effects of financial crises on hotels and the measures taken relative to the performance of the hotels under investigation [10]. The research focused on the quality of investment in the brand and not on the horizontal reduction of business costs. Determining the links between strategic management, uncertain external environments, and crises is an area on which researchers must focus more intensely in the future $[9,10]$. An attempt was made to approach strategic management from the point of view of the survival of hotel businesses, but in combination with the governmental choices at the economic level [31]. Regarding the Greek context, many studies have approached the effects of economic crises on tourism from the destination point of view [32], attempting to establish the necessary requirements to regain efficiency in the wider tourism sector [33], as well as the required marketing and planning strategies to get out of a crisis [12,34].

A significant number of papers have dealt with the strategic role of innovation and technology in the tourism industry, and particularly in the field of hospitality. There are various papers focusing on new technologies and their implementation during times of crisis, especially COVID-19 [35,36]. Knowledge management though machine learning technologies, innovation, and technology in general in the global context demand the use of disruptive technologies, involving all aspects of the tourism sector, from every stakeholder to every subdomain of the industry [36-39]. Hospitality businesses are characterized by the interaction between stakeholders, business digitalization and agility [40], and rethinking science, growth, and technology in response to COVID-19 [36]. The rapid development of technology allows tourism and hospitality enterprises to significantly increase the quality of their services [41]. In the post-COVID-19 landscape, hospitality businesses will need to draw on necessary knowledge from other sectors, such as that of governments, and will need to follow specific steps, such as: (1) start small and safe; (2) integrate data and service management; and (3) concentrate on the customer experience [42], along with technological enablers for websites [43]. Unless hotel owners and hospitality managers fully comprehend how new technologies function and adopt them into their strategic management processes, they will likely struggle to recover from the COVID-19 pandemic.

The above analysis focused on the economic crisis linked to the ongoing COVID-19 pandemic, as well as its anticipated economic impact on hospitality businesses in the post-COVID-19 period. It is likely that the hospitality sector will face a resourceless environment [18], and scholars are questioning the growth model of the tourism industry [22]. The questions and problems regarding the future of hospitality businesses have set an agenda for the sustainable development of the hospitality sector as a response to the non-optimistic outlook of its future so as to drive the sector to sustainable solutions $[16,19,20]$. However, the same discussion has taken place during previous crises $[44,45]$, 
which brings about questions regarding the ability of the hospitality sector to remain on track for sustainable development after the COVID-19 pandemic [16]. Thus, learning from past crises can help inform future strategic planning for hospitality businesses.

\subsection{Strategic Management and Tourism Businesses}

As regards strategy and strategic management, there are two different schools of thought in the literature [46]. The first school approaches strategic management as an ongoing and dynamic process [47-49] while the other school approaches it as a way of thinking for businesses [50-52]. Other researchers $[53,54]$ state that this demonstrates that a strategic approach is made in more of a multidisciplinary way. The key difference is that the former approach includes the strategic planning process within strategic management, while the latter approach addresses it as a set of decisions, a way of thinking in which strategic planning plays a major role. As far as the vital tourism and hospitality industry is concerned, a number of attempts have been made to revise strategic research in this field. Athiyaman in the tourism industry [55], as well as Olsen and Roper [56] and Tse and Olsen [52] in the hospitality sector, considerably revised the year-long literature on strategy. Strategic management in tourism, just like in other industries, involves action that aims to gain a competitive advantage through a unique standard of services [57]. The most important aims of strategic management in tourism consist of aligning the capabilities of a business with market opportunities [58] and understanding how hospitality businesses involve and add value through knowledge to develop their own strategy [13]. Thompson and Martin argued that tourism and hospitality businesses can only prosper and keep gaining a competitive advantage by using strategic management [59]. This can be achieved through the continuous organization of learning, defining a well-structured vision for the future, and adopting a flexible strategy and a unique approach with regard to employees and stakeholders. Along the same line of reasoning, many authors argued that strategic management represents the segments of actions required to realize the overall vision of a tourism organization, as well as to remain competitive [50]. Few studies have assessed the approach of strategic management through different parameters $[8,13]$. In recent years, a number of important academics have approached strategic management in hospitality businesses, in combination with digital transformation, smart hospitality, and smart cocreation, though this topic remains under-researched in the tourism sector $[7,60]$.

\subsection{Strategic Management, Performance, and Tourism Businesses}

One of the most important and interesting academic issues is the relationship between the strategy followed by businesses and their performance [61]. The strategic behaviors of tourism businesses, hotels in the case at hand, affect their performance, as there are certain strategic parameters, such as the size and type of hotel, its category, and its competitive advantage, that also affect its performance [62]. Taking into account the environment in which an organization operates, the choice and effective implementation of appropriate strategies should instinctively lead to better performance compared with an alternative [63]. Consequently, the environment of a tourism business is a significant parameter to be investigated through the lens of strategic management [8]. The performance of a tourism business depends on various factors including, among others, the strategy selected, the size of the business, and the industry in which it operates [62,64]. However, business performance is a multidimensional phenomenon with several interpretations in terms of both how to understand it and how to measure it [63]. The measurement of the performance of a tourism business can be converted into measurement of the effectiveness and efficiency of its strategic planning [65]. Traditionally, businesses use financial data to assess and measure their performance and overall strategy. In recent years, however, given the technological changes that have occurred, businesses have been searching for more efficient assessment systems [66,67]. Several researchers have placed emphasis on non-financial factors, such as the attainment of goals and their culture [68]. Reference is made below (Table 1) to the most important research approaches in the field of strategy and strategic management with respect to the performance of, primarily, tourism businesses. 
Table 1. Key research strategy and strategic management approaches in relation to the performance of hospitality businesses.

\begin{tabular}{|c|c|}
\hline Researches & Subject Matter of the Research \\
\hline [69] & $\begin{array}{l}\text { Strategic management factors relating to finances, clients, in-house business procedures, } \\
\text { and innovation and learning were analyzed. }\end{array}$ \\
\hline [70] & $\begin{array}{l}\text { The balanced scorecard (BSC) approach was proposed as the most useful tool to assess } \\
\text { tourism businesses and to implement strategic management processes. The authors } \\
\text { translated a business's mission and vision by integrating them into its strategy and into } \\
\text { more tangible and measurable goals and actions. }\end{array}$ \\
\hline [65] & $\begin{array}{l}\text { Four strategic planning parameters were defined, and then } 18 \text { characteristics that are } \\
\text { important in measuring strategic planning effectiveness were specified. }\end{array}$ \\
\hline [71] & $\begin{array}{l}\text { The views of strategic management officers in hotels were investigated in terms of their } \\
\text { wish to integrate and invest in technology as a strategic choice. }\end{array}$ \\
\hline$[72]$ & $\begin{array}{l}\text { The following priority factors for small- and medium-sized tourism businesses were } \\
\text { investigated: budget control, management of client relations, strategic management, } \\
\text { and cooperation. }\end{array}$ \\
\hline [62] & $\begin{array}{l}\text { Hotels' competitive strategies and competitive advantages were analyzed in relation to the } \\
\text { broader environment in which they operate, the first mention of strategic groups in the } \\
\text { literature on hospitality businesses. }\end{array}$ \\
\hline [73] & $\begin{array}{l}\text { The key performance resources and skills of businesses and the factors required to achieve } \\
\text { a competitive advantage through organizational agility were analyzed. }\end{array}$ \\
\hline$[74]$ & $\begin{array}{l}\text { The impact of strategic management on hotel performance and the impact of the following } \\
\text { factors were investigated: management strategy for client relations, strategic planning, } \\
\text { competitive position, Information and Communications Technology (ICT), and } \\
\text { organizational learning. }\end{array}$ \\
\hline [75] & $\begin{array}{l}\text { Strategic management in the tourism industry was examined through research aimed at } \\
\text { identifying strategic practices appropriate for hotels. }\end{array}$ \\
\hline [76] & $\begin{array}{l}\text { Macro- and micro-level critical evaluation of strategy and strategic management in the } \\
\text { hospitality business field. }\end{array}$ \\
\hline Own paper & $\begin{array}{l}\text { The implementation of strategic management in hospitality businesses was examined } \\
\text { during periods of economic crisis, which was linked to the COVID-19 pandemic in order to } \\
\text { avoid failures of the past. }\end{array}$ \\
\hline
\end{tabular}

\section{Methodology and Statistical Analysis}

In this research, performance is approached from the perspective of tourism businesses, in particular from the perspective of hotels, in which the use of strategic management was studied empirically through field research that included a questionnaire. The research aimed to measure the effectiveness of the use of strategic management and the extent to which it affects the performance of tourism business, ensuring sustainable growth in a highly competitive environment. An effort was made to use a holistic and upgraded approach to the strategy's research branch from the broader perspective of strategic management as a fundamental value of hotel businesses, that offers a competitive advantage by enhancing performance and which managers seek to implement [77]. The main purpose of this research was to measure the effectiveness of strategic management in tourism enterprises. The most interesting part of this research is that it was conducted in the middle of a financial crisis in Greece; as a result, we obtained conclusions on how hotel companies perceived their strategy during such a crisis. Through research, an attempt was made to extract data, such as how effectively hospitality businesses use strategic management during a period of crisis.

Trying to approach the above research question, we examined three factors (i.e., instrumental variables) as they emerged from the statistical processing (factor analysis) of the responses to a questionnaire set up for this purpose. The main research tool was a properly designed questionnaire, which consisted of 50 questions. As regards the preparation of the questionnaire, the strategic 
management planning parameters were based on the model concerning the strategic management process in tourism [56]. The strategic management parameters were based on the strategic management steps defined by Raju [58], and the strategic management planning parameters were based on the strategic management process analyzed by [26]. Finally, the performance characteristics of tourism businesses were adapted according to the theory $[62,63,65]$. More specifically, these factors concerned (a) the defining of strategies based on the market and clients, (b) the defining of strategies based on the internal and external environments, and (c) the defining of strategies based on competition. Creating these three components, we managed to provide the quantitative status of what we refer to as strategic management for tourism companies.

As a next step, an attempt was made to correlate these factors with three very important indicators (again based on the questionnaire) that measured the measurement of effectiveness, the enhanced effectiveness in the use of function, and the positive impact on the economic performance of hospitality businesses. We did this in order to examine whether, ultimately, there is an effect of strategic management (through the three above-mentioned factors) on the operational and financial status of hotel units, as well as on their effectiveness in general.

We found, according to the results of the correlations given in Table 2, that the factor of defining strategies based on the market and clients was positively correlated with the indicator of enhanced effectiveness in the use of function in relation to the company. This is because the Pearson coefficient (measuring the linear correlation) was equal to 0.652 (greater than zero) with $p<0.05$, which means that there is a statistically significant (and positive) correlation at a significance level of $5 \%$. The hypotheses examined here to reach the above conclusion were as follows Hypothesis 1 and 2:

Hypothesis $\left.\mathbf{( H}_{\mathbf{1}}\right)$. There is no correlation between strategies based on the market and clients and enhanced effectiveness in the use of function.

Hypothesis $\left(\mathbf{H}_{\mathbf{2}} \mathbf{)}\right.$. There is correlation between strategies based on the market and clients and enhanced effectiveness in the use of function.

Thus, based on the estimated $p<0.05$, Hypothesis 2 is not rejected at a significance level of $5 \%$. Therefore, we were able to conclude that the more you define strategies based on the internal and external environments, the higher the indicator of the enhanced effectiveness in the use of function in relation to the company.

Table 2. Correlations of factors and indicators.

\begin{tabular}{|c|c|c|c|c|}
\hline & & $\begin{array}{l}\text { Indicator of Enhanced } \\
\text { Effectiveness in the } \\
\text { Use of Function }\end{array}$ & $\begin{array}{l}\text { Indicator of the } \\
\text { Positive Impact of } \\
\text { Strategy on } \\
\text { Financial Data }\end{array}$ & $\begin{array}{c}\text { Measurement } \\
\text { of } \\
\text { Effectiveness }\end{array}$ \\
\hline \multirow{3}{*}{$\begin{array}{l}\text { Defining strategies based } \\
\text { on the market and clients }\end{array}$} & $\begin{array}{l}\text { Pearson } \\
\text { Correlation }\end{array}$ & 0.652 ** & $0.486^{* *}$ & $0.790^{* *}$ \\
\hline & Sig. (2-tailed) & 0.000 & 0.000 & 0.000 \\
\hline & $N$ & 109 & 114 & 115 \\
\hline \multirow{3}{*}{$\begin{array}{l}\text { Defining strategies based } \\
\text { on the internal and } \\
\text { external environments }\end{array}$} & $\begin{array}{l}\text { Pearson } \\
\text { Correlation }\end{array}$ & $0.623^{* *}$ & $0.493 * *$ & $0.649^{* *}$ \\
\hline & Sig. (2-tailed) & 0.000 & 0.000 & 0.000 \\
\hline & $N$ & 109 & 114 & 115 \\
\hline \multirow{3}{*}{$\begin{array}{l}\text { Defining strategies based } \\
\text { on competition }\end{array}$} & $\begin{array}{l}\text { Pearson } \\
\text { Correlation }\end{array}$ & $0.542^{* *}$ & $0.531^{* *}$ & $0.503^{* *}$ \\
\hline & Sig. (2-tailed) & 0.000 & 0.000 & 0.000 \\
\hline & $N$ & 108 & 113 & 114 \\
\hline
\end{tabular}


Following exactly the same logical approach of statistical tests to examine the correlation between the rest of the factors and indicators, we can conclude that the correlation observed between them (see Table 2 with the respective results) is positive and statistically significant at the level of $5 \%$.

Thus, comparing the indicators of effectiveness with the three factors that reflect quantitatively the terms of strategic management, we can conclude (judging by the positive and statistically significant sign of the correlation tests) that the implementation of strategic management is beneficial, at least for the sample of companies that were surveyed during the critical period of the economic and financial crisis in Greece.

However, it should be noted that the above conclusions do not apply universally to all companies, regardless of the size of the hospitality business. It is more of a characteristic of companies with a high star rating and a higher capacity. This is inferred from the results of the independence tests (chi-square tests) of the factors with these two characteristics, as well as those of the indicators with these characteristics (i.e., star rating and capacity).

It can be seen from Table 3 that many of the factors and indicators differ within their specific categories in terms of the company's size (business capacity), as well as in terms of the number of stars. For instance, checking the independence between business capacity and measurement of effectiveness, the chi-square statistic is equal to 8.152 with a $p=0.043<0.05$; therefore, the measurement of effectiveness depends on the size of the business. Our hypotheses were as follows Hypothesis 3 and 4:

Hypothesis $\left.\mathbf{( H}_{3}\right)$. Effectiveness measurement is independent from business capacity.

Hypothesis $\left.\mathbf{H}_{4}\right)$. Effectiveness measurement is not independent from business capacity.

Given that $p=0.043<0.05$, we were able to reject the null hypothesis.

Based on the average scores of the specific indicator (i.e., the measurement of effectiveness), we realized that the effect is more evident in companies with a higher capacity (chart 1 in Figure 1). For companies with less than 50 beds, the average effectiveness score was lower compared to those with more than 50 beds ( 22 vs. 18 on average). This differentiation was also reflected in the previous independence test.

Table 3. Results of comparing factors against the individual characteristics of hotel businesses.

\begin{tabular}{|c|c|c|c|c|c|c|}
\hline \multicolumn{7}{|c|}{ Factors and Indicators } \\
\hline & $\begin{array}{l}\text { Measurement } \\
\text { of } \\
\text { effectiveness }\end{array}$ & $\begin{array}{c}\text { Defining } \\
\text { strategies } \\
\text { based on the } \\
\text { market and } \\
\text { clients }\end{array}$ & $\begin{array}{c}\text { Defining } \\
\text { strategies } \\
\text { based on the } \\
\text { internal and } \\
\text { external } \\
\text { environments }\end{array}$ & $\begin{array}{c}\text { Defining } \\
\text { strategies } \\
\text { based on } \\
\text { competition }\end{array}$ & $\begin{array}{l}\text { Indicator of } \\
\text { enhanced } \\
\text { effectiveness } \\
\text { in the use of } \\
\text { function }\end{array}$ & $\begin{array}{l}\text { Indicator of } \\
\text { the positive } \\
\text { impact of } \\
\text { strategy on } \\
\text { financial } \\
\text { data }\end{array}$ \\
\hline \multicolumn{7}{|c|}{ Comparing factors and indicators per business capacity } \\
\hline Chi-square & 8.152 & 6.712 & 15.171 & 10.441 & 7.483 & 3.327 \\
\hline Df & 3 & 3 & 3 & 3 & 3 & 3 \\
\hline Asymp. Sig. & 0.043 & 0.082 & 0.002 & 0.015 & 0.058 & 0.344 \\
\hline \multicolumn{7}{|c|}{ Comparing factors and indicators per star rating } \\
\hline Chi-square & 26.178 & 14.788 & 18.472 & 6.103 & 18.636 & 25.079 \\
\hline Df & 4 & 4 & 4 & 4 & 4 & 4 \\
\hline Asymp. Sig. & 0 & 0.005 & 0.001 & 0.192 & 0.001 & 0.000 \\
\hline
\end{tabular}




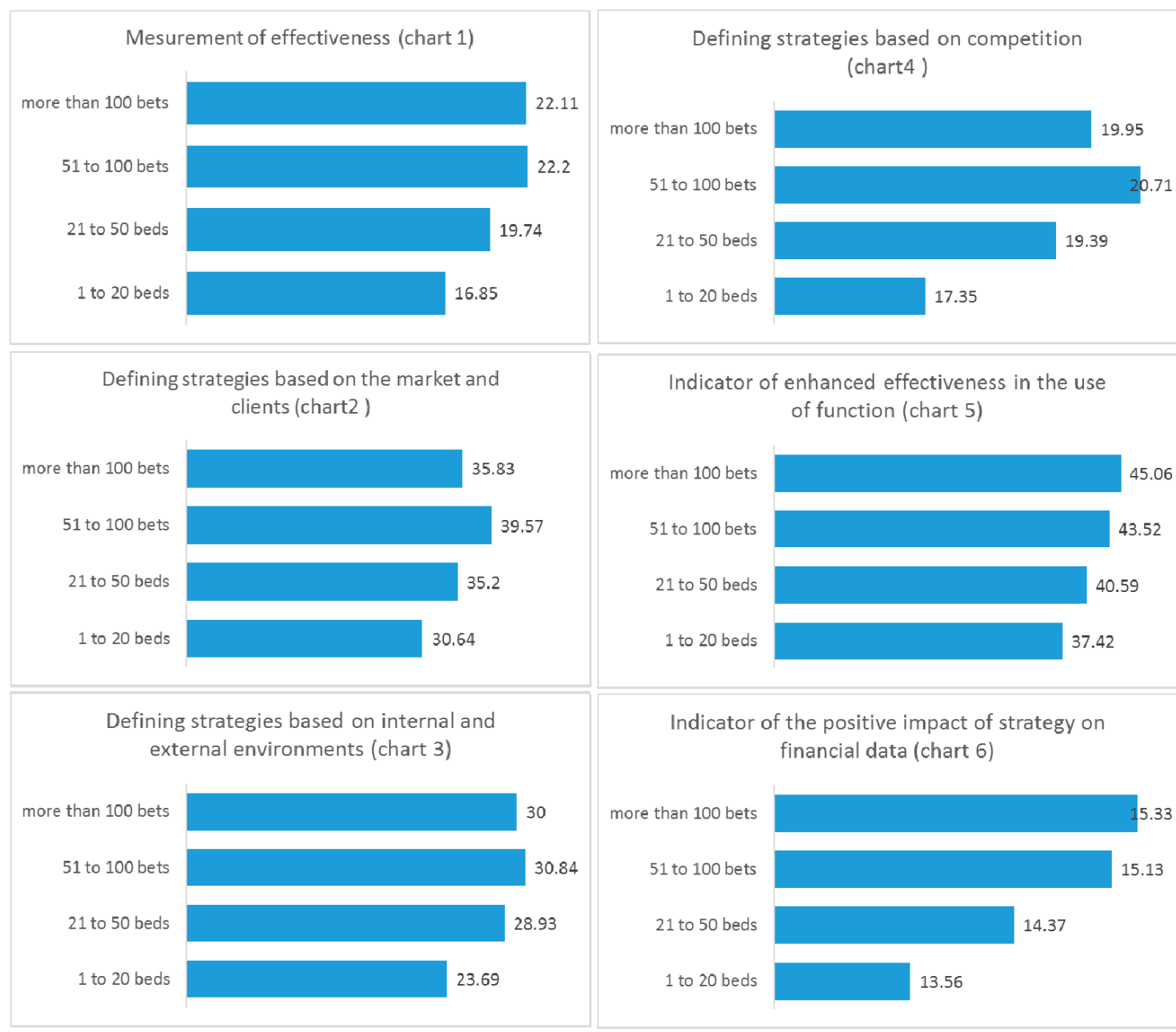

Figure 1. Analysis based on the number of beds of hotels.

If we exclude the following factors and indicators, then all of the others appear to depend on the size of the company (based on the chi-square results in Table 3): (a) defining strategies based on the market and clients; (b) the indicator of enhanced effectiveness in the use of function; and (c) the indicator of the positive impact of strategy on financial data. In addition, observing once again the results in Table 3, together with Figure 2 charts 7-12, only the indicator of enhanced effectiveness in the use of function seems to be independent of the number of stars in hotel ratings. The rest of the indicators and factors are statistically dependent (at the level of 5\%) on the number of stars in hotel ratings. 


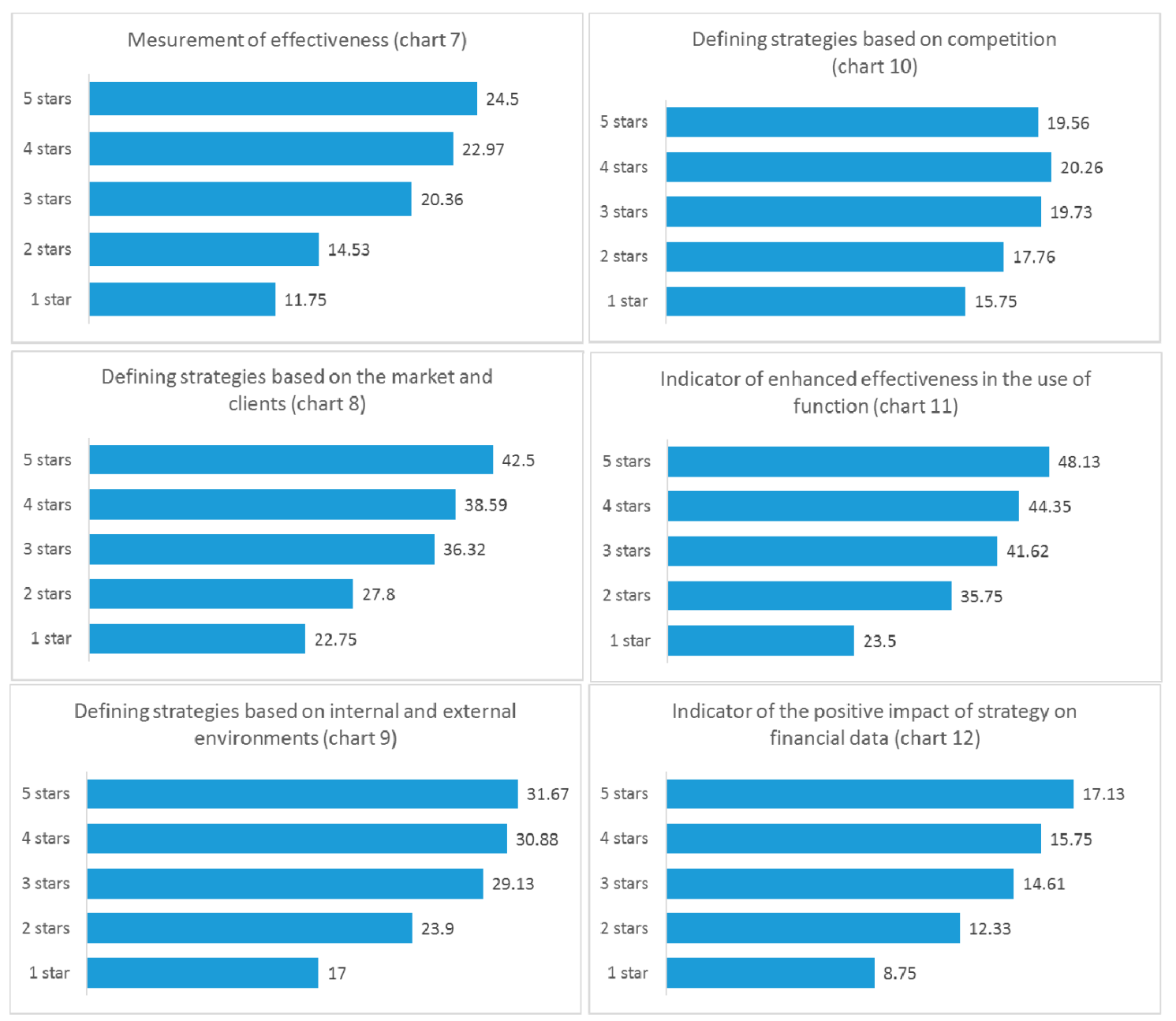

Figure 2. Analysis based on the star ratings of hotels.

\section{Research Results and Discussion}

The key factor identified by the analysis that has a significant impact on the businesses that participated in this research was the economic and political environment in Greece, which is understandable, while the intensity of competition was ranked lower. The overall economic environment as a significant factor has also been confirmed by other studies. However, a good number of businesses, i.e., $82 \%$, felt that they were different from their competitors. According to the businesses, their location and the quality of their services provided important competitive advantages, while innovation was ranked lower. They considered their vision, mission, goals, and objectives as the most important strategic management planning parameters. Most of the participants indicated that they had not used any strategic management tool other than identification of their internal strengths and weaknesses, as well as their external opportunities and threats (SWOT analysis), and most agreed that strategic management was important in enhancing their performance.

The research showed that a significant percentage of the participants understood and used individual procedures of strategic management and strategy in general, but lacked an overall picture of what strategic management meant for tourism businesses. Also, a large percentage of small three-, two-, and one-star hotel businesses stated that they were completely unaware of strategic management and, therefore, had not adopted it. Drawing upon the results, it seems that small firms are more reactive than proactive, due to the lack of an implemented strategic plan. The last one is linked to the trends in tourism in recent years, where customers are positively influenced by the sustainability practices of hotels $[5,78,79]$. This study confirmed, despite the fact that some hotels were not proactive, 
that market trends influenced entrepreneurial decisions, and sustainability practices could be set at the core. Adopting a management model based on strategic management requires qualified staff with appropriate knowledge and resources. Small- and medium-sized tourism businesses have limited resources at their disposal and low management capabilities. This, coupled with economic limitations, is a roadblock to development in an international competitive environment. Their poor management capabilities render them unable to compete with larger businesses, both at local and international levels. The findings are consistent with the literature, indicating that there is a lack of strategic management in the tourism and hospitality sector in order to cope with a crisis [80]. Strategic management can be equally successful in very small tourism businesses, enabling them to turn their disadvantages into advantages [81]. Setting up business networks can be beneficial for modern small- and medium-sized tourism businesses, particularly in the field of strategy, which requires a new approach for business models. In the current new environment, tourism businesses will have to address profit and risk through synergies within these cooperative networks [82].

As shown by the research, there are specific strategic management factors that can help enhance business performance and, more broadly, business functioning. These factors include defining the vision, mission, long-term goals (marketing goals in particular), market analysis through segmentation, alternative strategies, optimization of these strategies, and analysis of the needs of tourists, as well as strategy implementation assessment of a tourism business. Other critical factors identified by this research that hotel businesses need to focus on at all times include emphasis on technological developments, quality, and innovation, as well as differentiation of services. Indeed, the capability of tourism businesses seems to play an important role [12]. Other critical factors that affect performance and effectiveness include competition in the industry and taking measures to cope with the volatile economic environment in which businesses have to operate.

Overall, these findings are consistent with the literature, indicating that there is a lack of strategic management in the tourism and hospitality sector in order to cope with a crisis [80]. This is why this paper argues that, in the post-COVID-19 tourism environment, there will be a need for transformation from embedded sustainability $[15,19]$ to the strategic management of hospitality businesses as a response to the economic crisis caused by the COVID-19 pandemic.

\section{Conclusions}

As shown by this paper, the new environment in which tourism businesses have to operate greatly stresses the importance of strategic management. The management bodies of tourism businesses need to adopt a well-defined vision and mission, as well as specified values, in order to understand both the tourism product they offer and that offered by competitors in order to keep up-to-date with changes in the external environment at all times, which could have a significant impact on them, and should become better acquainted with their clients' and would-be clients' characteristics. A sustainable competitive advantage can only be gained through a client-oriented approach and through the emphasis placed on clients by the business itself. Through systematic knowledge, such businesses will manage to coordinate different skills and integrate multiple flows of innovation and technology, which will be useful for making requisite decisions, ensuring secure and sustainable growth, and being able to utilize suitable analysis and revise their specified directions at regular intervals as appropriate. Through target setting in accordance with the above guidance, tourism businesses will strengthen their strategic position in the industry's value chain, but only by making clients a priority and quality a dominant goal to be attained through the constant pursuit of innovation.

With that said, this paper sets some future research avenues related to (1) investigating strategic management in periods of crisis and carrying out comparative analysis of different countries suffering from austerity measures and a resourceless economic environment; (2) conducting more extensive research in small businesses in the tourism sector and investigating their special characteristics through the lens of how they can overcome a crisis through sustainable development practices; and (3) analyzing the micro-level economic consequences in light of the COVID-19 pandemic, which has caused a negative 
impact on tourism activities, through the lens of strategic management and its implementation. In light of the digitalization and implementation of new technologies forced by the COVID-19 pandemic, strategic management in hospitality has to be examined through the digitalization of customer services [42], technological enablers for online services [43], and new technologies [41]. While this research investigates decisions based on the market and clients during economic crises, there is a need for more intensive research on dynamic pricing as a strategy in hospitality businesses [81,82] during and after the COVID-19 pandemic as a strategy to mitigate the impact on revenues.

Author Contributions: Data curation, S.V.; formal analysis, S.V.; investigation, S.V.; methodology, S.V.; project administration, N.A.; supervision, N.A.; validation, N.A. Both authors have read and agreed to the published version of the manuscript.

Funding: This research received funding by the Neapolis University Pafos Research Department.

Conflicts of Interest: The authors declare no conflict of interest.

\section{References}

1. World Travel and Tourism Council (WTTC). Economic Impact of Travel \& Tourism: 2019 Annual Update; World Travel and Tourism Council: London, UK, 2019.

2. Bank of Greece, Travel Services Report. Available online: https://www.bankofgreece.gr/en/statistics/externalsector/balance-of-payments/travel-services (accessed on 30 July 2020).

3. Hellenic Chamber of Hotels. Hotel Dynamic of Greece-Announcement; Hellenic Chamber of Hotels: Athens, Greece. Available online: https://www.grhotels.gr/wp-content/uploads/2020/02/2019-Hotels_total.pdf (accessed on 30 June 2020).

4. Cárdenas-García, P.J.; Sánchez-Rivero, M.; Pulido-Fernández, J.I. Does tourism growth influence economic development? J. Travel Res. 2015, 54, 206-221. [CrossRef]

5. Sánchez-Rivero, M.; Pulido-Fernández, J.I.; Cárdenas-García, P.J. Tourism Growth Versus Economic Development: An Analysis by Multivariate Techniques. In Quantitative Methods in Tourism Economics; Matías, A., Nijkamp, P., Sarmento, M., Eds.; Physica Verlag: Heidelberg, Germany, 2013; pp. 235-251.

6. Köseoglu, M.A.; Morvillo, A.; Altin, M.; De Martino, M.; Okumus, F. Competitive intelligence in hospitality and tourism: A perspective article. Tour. Rev. 2019, 75, 239-242. [CrossRef]

7. Buhalis, D.; Harwood, T.G.; Bogicevic, V.; Viglia, G.; Beldona, S.; Hofacker, C.F. Technological disruptions in services: Lessons from tourism and hospitality. J. Serv. Manag. 2019, 30, 484-506. [CrossRef]

8. Okumus, F.; Köseoglu, M.A.; Morvillo, A.; Altin, M. Scientific progress on strategic management in hospitality and tourism: A state-of-the-art. Tour. Rev. 2017, 72, 261-273. [CrossRef]

9. Ritchie, B.W.; Jiang, Y. A review of research on tourism risk, crisis and disaster management: Launching the annals of tourism research curated collection on tourism risk, crisis and disaster management. Ann. Tour. Res. 2019, 79, 102812. [CrossRef]

10. Bremser, K.; del Mar Alonso-Almeida, M.; Llach, J. Strategic alternatives for tourism companies to overcome times of crisis. Serv. Bus. 2018, 12, 229-251. [CrossRef]

11. Beirman, D. Restoring Tourism Destinations in Crisis: A Strategic Marketing Approach; Routledge: London, UK, 2020.

12. Pappas, N.; Brown, A.E. Entrepreneurial decisions in tourism and hospitality during crisis. Manag. Decis. 2020, 1-35. [CrossRef]

13. Köseoglu, M.A.; Law, R.; Okumus, F.; Barca, M.; Dogan, I.C. Evolution of strategic management research lines in hospitality and tourism. J. Hosp. Mark. Manag. 2019, 28, 690-710. [CrossRef]

14. Apostolopoulos, N.; Al-Dajani, H.; Holt, D.; Jones, P.; Newbery, R. Entrepreneurship and the Sustainable Development Goals; Emerald Publishing Ltd.: Bingley, UK, 2018.

15. Galvani, A.; Lew, A.A.; Perez, M.S. COVID-19 is expanding global consciousness and the sustainability of travel and tourism. Tour. Geogr. 2020, 22, 567-576. [CrossRef]

16. Jones, P.; Comfort, D. A commentary on the COVID-19 crisis, sustainability and the service industries. J. Public Aff. 2020, e2164. [CrossRef]

17. Pulido-Fernández, J.I.; Cárdenas-García, P.J.; Espinosa-Pulido, J.A. Does environmental sustainability contribute to tourism growth? An analysis at the country level. J. Clean. Prod. 2019, 213, 309-319. [CrossRef] 
18. Brouder, P. Reset redux: Possible evolutionary pathways towards the transformation of tourism in a COVID-19 world. Tour. Geogr. 2020, 22, 484-490. [CrossRef]

19. Chang, C.-L.; McAleer, M.; Ramos, V. A charter for sustainable tourism after COVID. Sustainability 2020, 12, 3671. [CrossRef]

20. Romagosa, F. The COVID-19 crisis: Opportunities for sustainable and proximity tourism. Tour. Geogr. 2020, 22, 690-694. [CrossRef]

21. Smeral, E. The impact of the financial and economic crisis on European tourism. J. Travel Res. 2009, 48, 3-13. [CrossRef]

22. Gössling, S.; Scott, D.; Hall, C.M. Pandemics, tourism and global change: A rapid assessment of COVID. J. Sustain. Tour. 2020, 1-20. [CrossRef]

23. Sarışık, M.; Sarı, D.; Sarı, S.; Halis, M. Tourism sector in order to recovering from the recession: Comparison analyses for turkey. Procedia Soc. Behav. Sci. 2011, 24, 181-187. [CrossRef]

24. Henderson, J.C. Tourism Crises: Causes, Consequences \& Management; Elsevier: London, UK, 2007.

25. Kimes, S.E. Hotel Revenue Management in an Economic Downturn: Results of an International Study; No. 12; Cornell University, School of Hotel Administration: Ithaca, NY, USA, 2009.

26. Enz, C.A.; Kosová, R.; Lomanno, M. The Impact of Terrorism and Economic Shocks on U.S. Hotels: Cornell Hospitality Report; Cornell University: Ithaca, NY, USA, 2011.

27. Boukas, N.; Ziakas, V. Impacts of the global economic crisis on Cyprus tourism and policy responses. Int. J. Tour. Res. 2012, 15, 329-345. [CrossRef]

28. Bilić, I.; Pivčević, S.; Čevra, A. crisis management in hotel business-insights from Croatia. Commun. Manag. Rev. 2017, 2, 100-118. [CrossRef]

29. Eugenio-Martin, J.L.; Campos-Soria, J.A. Economic crisis and tourism expenditure cutback decision. Ann. Tour. Res. 2014, 44, 53-73. [CrossRef]

30. Campos-Soria, J.A.; Inchausti-Sintes, F.; Eugenio-Martin, J.L. Understanding tourists' economizing strategies during the global economic crisis. Tour. Manag. 2015, 48, 164-173. [CrossRef]

31. Dangla, R.R. Crisis and survival strategy in the hospitality industry: An approach through financial statements. Tour. Manag. Stud. 2016, 12, 117-126.

32. Papatheodorou, A.; Arvanitis, P. Tourism and the Economic Crisis in Greece: Regional Perspectives. Reg. Dévelopment 2014, 39, 183-203.

33. Agiomirgianakis, G.M.; Magoutas, A.I.; Sfakianakis, G. Determinants of profitability in the Greek tourism sector revisited: The impact of the economic crisis. J. Tour. Hosp. Manag. 2013, 1, $12-17$.

34. Pappas, N. Marketing Hospitality Industry in an Era of Crisis. Tour. Plan. Dev. 2015, 12, 333-349. [CrossRef]

35. Brainard, J. Scientists are Drowning in COVID-19 Papers. Can New Tools Keep Them Afoat? Available online: https:/www.sciencemag.org/news/2020/05/scientists-are-drowning-covid-19-papers-can-new-toolskeepthem-afoat (accessed on 21 May 2020).

36. Gretzel, U.; Fuchs, M.; Baggio, R.; Hoepken, W.; Law, R.; Neidhardt, J.; Pesonen, J.; Zanker, M.; Xiang, Z. e-Tourism beyond COVID-19: A call for transformative research. Inf. Technol. Tour. 2020, 22, 187-203. [CrossRef]

37. Benckendorf, P.J.; Xiang, Z.; Sheldon, P.J. Tourism Information Technology, 3rd ed.; CABI: Boston, MA, USA, 2019.

38. Werthner, H.; Alzua-Sorzabal, A.; Cantoni, L.; Dickinger, A.; Gretzel, U.; Jannach, D.; Neidhardt, J.; Pröll, B.; Ricci, F.; Scaglione, M.; et al. Future research issues in IT and tourism. Inf. Technol. Tour. 2015, 15, 1-15. [CrossRef]

39. Xiang, Z. From digitization to the age of acceleration: On information technology and tourism. Tour. Manag. Perspect. 2018, 25, 147-150. [CrossRef]

40. Buhalis, D.; Amaranggana, A. Smart Tourism Destinations Enhancing Tourism Experience through Personalisation of Services; Springer International Publishing: Poole, UK, 2015.

41. Ivanov, S.; Webster, C. Robots, Artificial Intelligence and Service Automation in Travel, Tourism and Hospitality; Emerald Publishing Limited: Bradford, UK, 2019.

42. Nili, A.; Barros, A.1.; Tate, M. The public sector can teach us a lot about digitizing customer service. MIT Sloan Manag. Rev. 2019, 60, 84-87. 
43. Nili, A.; Tate, M.; Gable, G.G. A typology of technological enablers of website service failure prevention. In Proceedings of the 18th Pacific Asia Conference on Information Systems, PACIS 2014, Chengdu, China, 24-28 June 2014; p. 78.

44. Sheldon, P.J.; Dwyer, L. The Global Financial Crisis and Tourism: Perspectives of the Academy. J. Travel Res. 2010, 49, 3-4. [CrossRef]

45. De Sausmarez, N. Crisis Management, Tourism and Sustainability: The Role of Indicators. J. Sustain. Tour. 2007, 15, 700-714. [CrossRef]

46. Taylor, M.H. A Test of the Co-Alignment Principle in Independent Hotels: A Case Study. Ph.D. Thesis, Faculty of Virginia Polytechnic Institute and State University, Blacksburg, VA, USA, 2002.

47. Henderson, B.D. On Corporate Strategy; Abt Books: Cambridge, MA, USA, 1979.

48. Backer, J.B. The historical development of the strategic management concept. Acad. Manag. Rev. 1980, 5, 219-224. [CrossRef]

49. Thompson, A.A., Jr.; Strickland, A.J., III. Strategic Management, 3rd ed.; Richard, D., Ed.; Irvin: Chicago, IL, USA, 1996.

50. Mintzberg, H.; Ahlstrand, B.W.; Ahlstrand, B.; Lampel, J. Strategy Safari: A Guided Tour through the Wilds of Strategic Management; Free Press: New York, NY, USA, 2005.

51. Webster, M.; Hudson, T. Strategic management: A theoretical overview and its application to the hospitality industry. In Strategic Hospitality Management: Theory and Practice for the 1990s; Teare, R., Boer, A., Eds.; Cassell Education: London, UK, 1991; pp. 9-30.

52. Olsen, M.D.; Tse, E.C.; West, J.J. Strategic Management in the Hospitality Industry, 2nd ed.; John Wiley and Sons, Inc.: New York, NY, USA, 1998.

53. Tribe, J.; Liburd, J.J. The tourism knowledge system. Ann. Tour. Res. 2016, 57, 44-61. [CrossRef]

54. Durand, R.; Grant, R.M.; Madsen, T.L. The expanding domain of strategic management research and the quest for integration. Strat. Manag. J. 2016, 38, 4-16. [CrossRef]

55. Athiyaman, A. The interface of tourism and strategy research: An analysis. Tour. Manag. 1995, 16, 447-453. [CrossRef]

56. Chon, K.S.; Olsen, M.D. Applying Strategic Management Process in Tourism Organizations. Tour. Manag. 1990, 11, 206-213. [CrossRef]

57. Lashley, C. Marketing hospitality and tourism experiences. In Handbook of Hospitality Marketing Management; Oh, H., Pizam, A., Eds.; Elsevier Ltd.: Oxford, UK, 2008; pp. 3-31.

58. Raju, G.P. Tourism Marketing and Management; Manglam Publications: Delhi, India, 2009.

59. Thompson, A.A.J.; Martin, F. Strategic Management: Awareness and Change, 5th ed.; Thomson Learning: London, UK, 2005.

60. Buhalis, D.; Sinarta, Y. Real-Time co-creation and nowness service: Lessons from tourism and hospitality. J. Travel Tour. Mark. 2019, 36, 563-582. [CrossRef]

61. McPhatter, M.R.; Ziemnowicz, C.; Spillan, J.E. Sustainable strategic management: The case of Poland. Int. J. Sustain. Strat. Manag. 2011, 3, 126. [CrossRef]

62. Claver-Cortés, E.; Molina-Azorín, J.F.; Pereira-Moliner, J. The impact of strategic behaviours on hotel performance. Int. J. Contemp. Hosp. Manag. 2007, 19, 6-20. [CrossRef]

63. Murthy, B. Measurement of the Strategy Construct in the Lodging Industry, and the Strategy-Performance Relationship. Ph.D. Thesis, Faculty in Hospitality and Tourism Management, Virginia Polytechnic Institute and State University, Blacksburg, VA, USA, 1994.

64. Pereira-Moliner, J.; Claver-Cortés, E.; Molina-Azorín, J.F. Strategy and Performance in the Spanish Hotel Industry. Cornell Hosp. Q. 2010, 51, 513-528. [CrossRef]

65. Phillips, P.A.; Moutinho, L. The Strategic Planning Index: A Tool for Measuring Strategic Planning Effectiveness. J. Travel Res. 2000, 38, 369-379. [CrossRef]

66. Kennerley, M.; Neely, A.; Neely, A.D. A framework of the factors affecting the evolution of performance measurement systems. Int. J. Oper. Prod. Manag. 2002, 22, 1222-1245. [CrossRef]

67. McAdam, R.; Bailie, B. Business performance measures and alignment impact on strategy. Int. J. Oper. Prod. Manag. 2002, 22, 972-996. [CrossRef]

68. McAdam, R.; Bannister, A. Business performance measurement and change management within a TQM framework. Int. J. Oper. Prod. Manag. 2001, 21, 88-108. [CrossRef] 
69. Kaplan, R.S.; Norton, D.P. The balanced scorecard-Measures that drive performance. Harv. Bus. Rev. 1991, 70, 71-79.

70. Kaplan, R.; Norton, D. Alignment: Using the Balanced Scorecard to Create Corporate Synergies; Harvard School Press: Boston, MA, USA, 2006.

71. Lee, S.-C.; Barker, S.; Kandampully, J. Technology, service quality, and customer loyalty in hotels: Australian managerial perspectives. Manag. Serv. Qual. Int. J. 2003, 13, 423-432. [CrossRef]

72. Phillips, P.; Louvieris, P. Performance Measurement Systems in Tourism, Hospitality, and Leisure Small Medium-Sized Enterprises: A Balanced Scorecard Perspective. J. Travel Res. 2005, 44, 201-211. [CrossRef]

73. Spillan, J.; Kara, A.; King, D.O.; McGinnis, M.A. Market orientation and firm performance: An empirical analysis of ghanaian microenterprises. J. Glob. Mark. 2013, 5, 258-272. [CrossRef]

74. Mutindi, U.J.M.; Namusonge, G.S.; Obwogi, J. Effects of strategic management drivers on the performance of hotel industry in Kenyan coast. Eur. J. Bus. Innov. Res. 2013, 2, 63-92.

75. Bordean, O.N.; Borza, A. Strategic Management practices within the Romanian Hotel Industry. Amfiteatru Econ. 2014, 8, 1238-1252.

76. Guerras-Martin, L.A.; Madhok, A.; Montoro-Sanchez, A. The evolution of strategic management research: Recent trends and current directions. BRQ Bus. Res. Q. 2014, 17, 69-76. [CrossRef]

77. Grant, R.M. Contemporary Strategy Analysis, 9th ed.; John Wiley and Sons: West Sussex, UK, 2016.

78. Prud'Homme, B.; Raymond, L. Sustainable development practices in the hospitality industry: An empirical study of their impact on customer satisfaction and intentions. Int. J. Hosp. Manag. 2013, 34, 116-126. [CrossRef]

79. Xu, X.; Gursoy, D. Influence of sustainable hospitality supply chain management on customers' attitudes and behaviors. Int. J. Hosp. Manag. 2015, 49, 105-116. [CrossRef]

80. Mair, J.; Ritchie, B.W.; Walters, G. Towards a research agenda for post-disaster and post-crisis recovery strategies for tourist destinations: A narrative review. Curr. Issues Tour. 2016, 19, 1-26. [CrossRef]

81. Knight, G. Entrepreneurship and marketing strategy: The SME under globalization. J. Int. Mark. 2000, 8, 12-32. [CrossRef]

82. Johann, M. The relationship building strategy with partners in tourism market. Eur. J. Tour. Hosp. Recreat. Spec. Issue 2014, 95-105.

(C) 2020 by the authors. Licensee MDPI, Basel, Switzerland. This article is an open access article distributed under the terms and conditions of the Creative Commons Attribution (CC BY) license (http://creativecommons.org/licenses/by/4.0/). 